\title{
Exosomes as Messengers between Mother and Fetus in Pregnancy
}

\author{
Liliana Czernek (D) and Markus Düchler* ${ }^{(D)}$ \\ Department of Bioorganic Chemistry, Centre of Molecular and Macromolecular Studies, Polish Academy of \\ Sciences, 112, Sienkiewicza Street, 90-363 Lodz, Poland; lilianaczernek@gmail.com \\ * Correspondence: mduchler@cbmm.lodz.pl; Tel.: +48-42-6803-220
}

Received: 14 May 2020; Accepted: 12 June 2020; Published: 15 June 2020

\begin{abstract}
The ability of exosomes to transport different molecular cargoes and their ability to influence various physiological factors is already well known. An exciting area of research explores the functions of exosomes in healthy and pathological pregnancies. Placenta-derived exosomes were identified in the maternal circulation during pregnancy and their contribution in the crosstalk between mother and fetus are now starting to become defined. In this review, we will try to summarize actual knowledge about this topic and to answer the question of how important exosomes are for a healthy pregnancy.
\end{abstract}

Keywords: placenta; exosomes; extracellular vesicles; pregnancy; embryo implantation

\section{Introduction}

Intensive maternal-fetal information exchange is required to establish and to maintain a healthy pregnancy. The placenta is the most important organ in this respect, performing vital functions for the fetus to support its growth and survival and to maintain the pregnancy [1]. The placental assignments also include the control and regulation of the communication between the mother and the developing child [2]. In general, cellular communication is mediated through direct cell-to-cell contacts, soluble factors, intercellular nanotubes, and extracellular vesicles [3]. Placental cells of both maternal and embryonic origin, secrete not only soluble endocrine mediators but also extracellular vesicles, including exosomes. For the maternal immune system, a pregnancy poses an exceptional challenge as the embryo constitutes a foreign tissue in immunological terms that must not be destroyed. A finely tuned immunosuppression has to take place to avoid rejection of the embryo. In addition, other pregnancy complications can result from dysfunctional placental communication causing severe danger for the survival of the fetus [4]. In this review, we summarize the role of exosomes in healthy and pathological pregnancies.

\section{Exosomes and Other Extracellular Vesicles}

Extracellular vesicles (EV) are heterogeneous populations of cell-derived membrane vesicles released by eukaryotic and prokaryotic cells to the extracellular space. The classification of EVs is based on the origin and size of the vesicle (Figure 1) [5]. The human placenta releases a wide variety of EVs including macrovesicles (syncytial nuclear aggregates, 20-100 $\mu \mathrm{m}$ ), microvesicles, apoptotic bodies, and nanovesicles (exosomes) $[3,6]$. The function of syncytial nuclear aggregates is unclear as they can contain tens or hundreds of nuclei and could represent the remnants of dying syncytiotrophoblasts. Microvesicles are budding from the cell membrane and typically show a diameter of 100 to $1000 \mathrm{~nm}$. Exosomes were considered originally to be cellular "debris", but do in fact play an important role in the body as mediators of intercellular communication. They are the smallest representatives of EVs with a diameter of 30 to $150 \mathrm{~nm}$ and are produced by a defined pathway. Budding from the membrane of the multivesicular body, a part of the endosomal compartment, their composition including their cargo 
loosely follows certain formation rules resulting in a heterogeneous population of vesicles-with some communalities. Although the origin of microvesicles and exosomes is well known, the experimental discrimination of these vesicles types is difficult, so the terms are sometimes subsumed as extracellular vesicles [6]. In this review, we use the terms exosomes or extracellular vesicles according to the usage in the reviewed publications. Exosomes consist of a lipid bilayer with the same orientation as the plasma membrane and contain a variety of proteins and nucleic acids-some of which are enriched especially in these vesicles. Their content varies due to cell type and environment conditions. They are produced by almost every cell type-as well by cancer cells. Once released into the extracellular space, exosomes may act locally to modify the activity of neighboring cells or distally after entry into circulating bodily fluids. Exosomes were found in most biological fluids including blood, lymph, saliva, milk, amniotic fluid, lachrymal and mammary gland secretions [7].

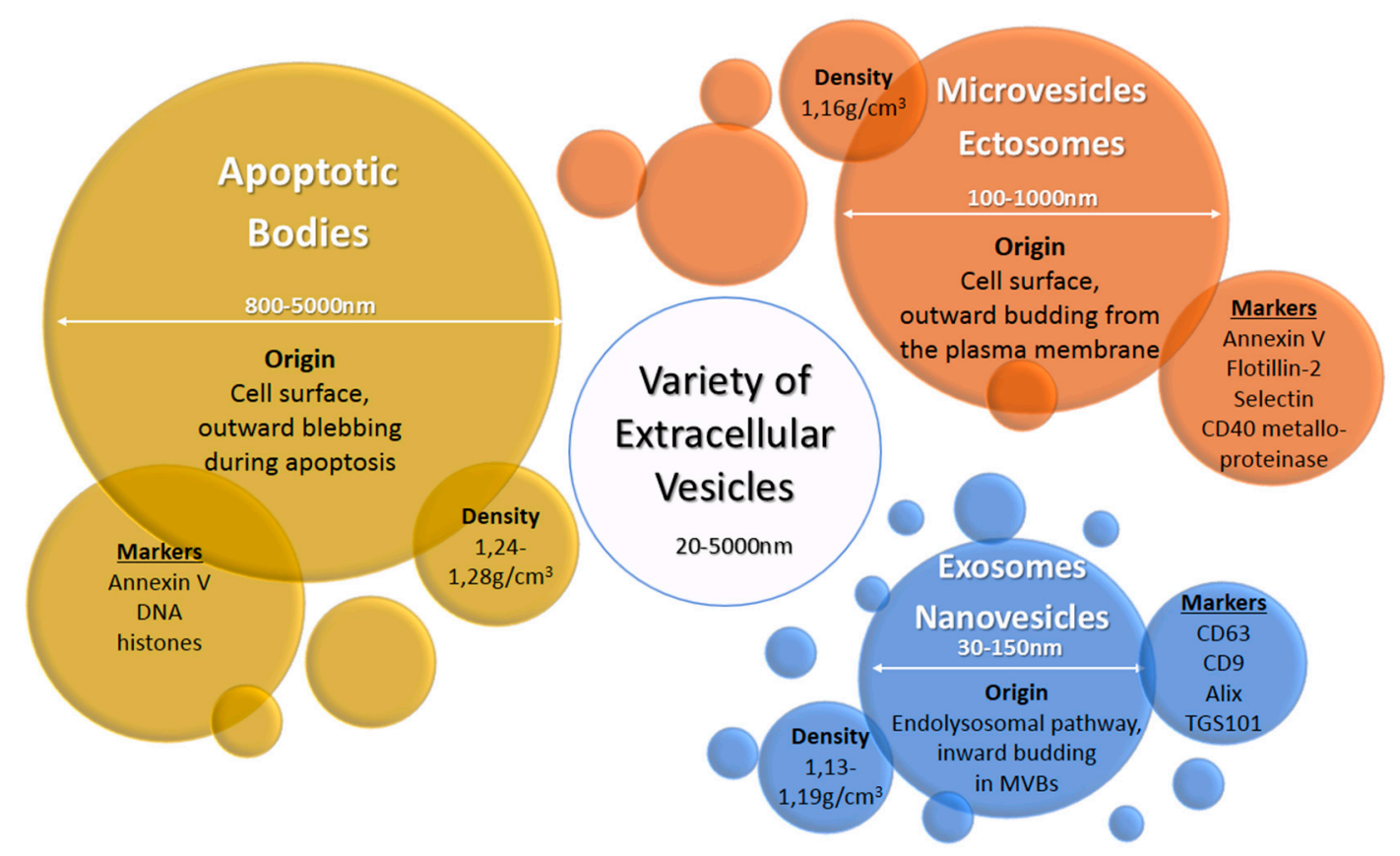

Figure 1. Origin, size, density, and typical markers of major extracellular vesicle subclasses [6,7].

\section{The Human Pregnancy}

After fertilization, the zygote starts to move through the fallopian tube where the first mitoses occur [8]. The first cell doublings result in the morula, comprising 16 cells, which develops further into the blastocyst. The blastocyst reaches the uterus and implants into the modified part of the endometrium of the uterus called decidua. The blastocyst contains two kinds of cells that are the product of the first differentiation processes, the inner cell mass, and the surrounding trophoblasts. The inner cell mass develops into embryoblasts that form the embryonic disc. In addition, the cells of the trophoblast undergo further differentiation into an inner layer comprising the cytotrophoblasts (CT; sometimes villous cytotrophoblasts, VCT), and an outer layer containing the syncytiotrophoblasts (SCT). In the blastocyst stage, the embryonic anlage is nurtured by diffusion of nutrients from the maternal blood. The placenta is a temporary organ that develops when the blastocyst becomes implanted into the maternal endometrium and is composed of cells from both the embryo and the uterus. Villous tree structures are formed that contain a network of blood vessels. In the placenta, an intensive exchange of oxygen, $\mathrm{CO}_{2}$, and nutrients takes place between the maternal and the embryonic circulation. The embryonic disc undergoes further differentiation processes that give rise to the gastrula, a trilaminar disc comprised of the three germ layers ectoderm, mesoderm, and endoderm. During the next weeks, early progenitors for all kinds of tissues are formed. The growing embryo detaches from the uterus wall staying connected through the umbilical cord. The cord contains blood 
vessels of the embryonic circulation and connects it to the placenta where material transfer takes place without direct mixing of the embryonic and maternal blood.

\section{The Placenta as the Interface Between Maternal and Fetal Organisms}

The crosstalk between fetus and mother can occur as a simple diffusion of molecules through tissue layers or in a better protected manner through extracellular vesicles, especially via exosomes (Figure 2) [9,10]. Embryo-derived exosomes encapsulate a variety of different proteins and nucleic acids (microRNA, messenger RNA, long non-coding RNA, DNA) and can subsequently be taken up by cells of the maternal immune and vascular systems. They modulate the maternal physiology to cause or adapt it to pregnancy-induced changes [9]. The release of placenta derived exosomes into the maternal circulation has been demonstrated in healthy and pathologic pregnancies $[3,9,10]$. Placenta-derived exosomes may be differentiated from other exosomes by the presence of placenta-specific miRNAs or proteins. One of them is placental alkaline phosphatase (PLAP), a syncytiotrophoblast-specific protein. Moreover, trophoblast-derived exosomes carry characteristic trans-membrane proteins such as human leukocyte antigen G (HLA-G) [11]. A recent study demonstrated that the total amount and the specific placenta-derived exosomes could be determined using quantum dots coupled with CD63 and PLAP antibodies, respectively. Quantification of placental exosomes in maternal plasma reflects fetal growth and it may be a useful indicator of placental function [12].

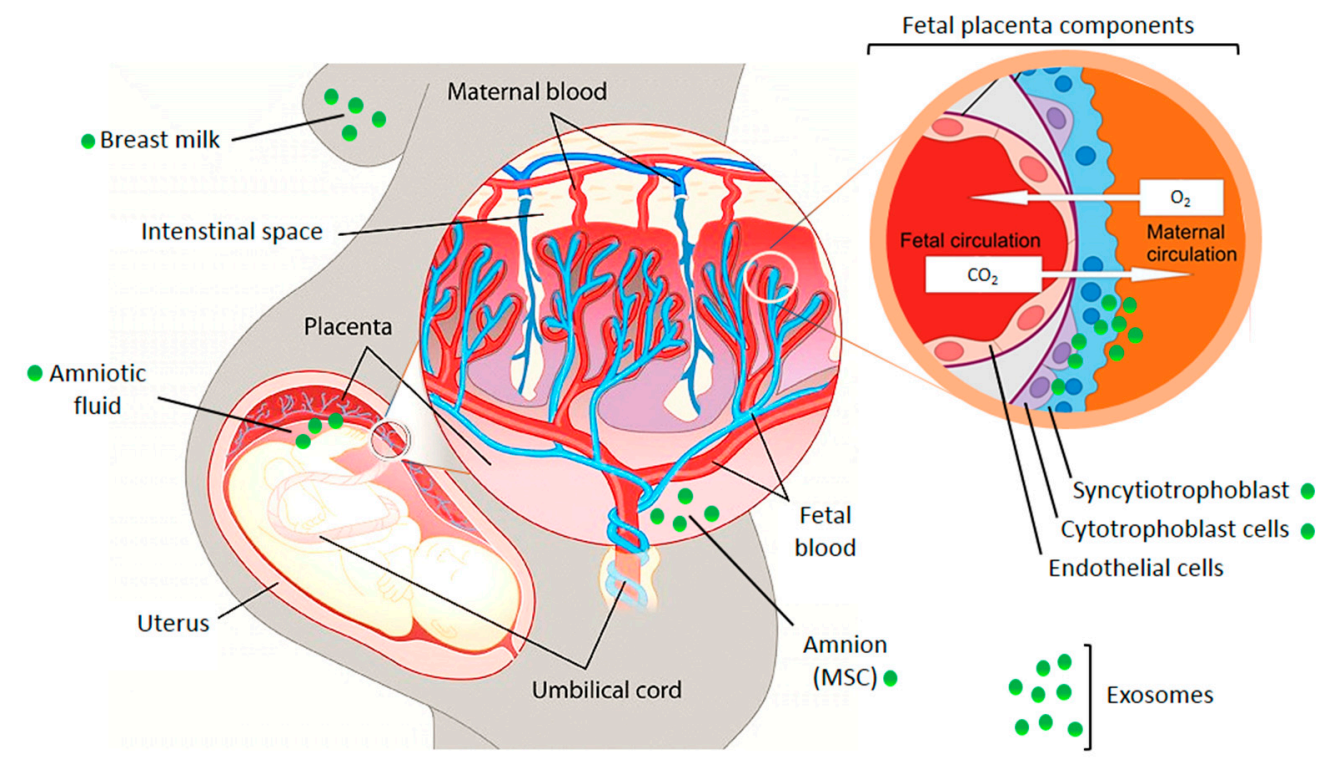

Figure 2. Illustration of the fetal placental barrier that separates fetal and maternal circulations in the human placenta. Places of exosome appearance are indicated. MSC-mesenchymal stem cells. The picture was composed using publicly available graphics from The Alcohol Pharmacology Education Partnership at the Duke University Medical Center [13] and from Christiane Albrecht, University of Bern, with her friendly permission [14].

Fetal-derived exosomes travel to the maternal side to potentially transmit signals to the uterus and cervix. It was even suggested that inflammatory signals delivered by exosomes could contribute to the onset of parturition [15]. Exosomes as potential paracrine mediators triggering labor were also identified in mice. Birth could be experimentally induced by exosomes in the absence of systemic progesterone withdrawal, which is otherwise a requirement for birth initiation [9].

Through the effects on the maternal organism, the released exosomes also support growth and survival of the fetus, therefore one would expect an increased production of exosomes during pregnancy. This hypothesis was confirmed, as the concentration of exosomes in maternal peripheral blood was $\sim 20$-fold greater than that observed in non-pregnant women [16]. The concentration of placenta-derived 
exosomes in maternal plasma increases in normal pregnant women as gestation progresses, with a maximum concentration reported at term $[3,17]$. The increase with gestational age can be observed already during the first trimester of pregnancy, starting as early as in the sixth week-even before the intervillous circulation is fully developed. Hypoxia and/or hyperglycemia inside the uterus result in an increased exosome release from syncytiotrophoblasts which can facilitate extravillous trophoblast invasion and proliferation [18].

In general, research techniques to study the placenta-derived exosomes use cell cultures of trophoblasts (primary and cell lines), chorionic villi explants, placental perfusion, plasma and urine from pregnant women. Main areas of interest about exosomes in pregnancy include: demonstration of the exchange of EVs between fetus and mother; the role of EVs in implantation; the establishment of immune tolerance; and the regulation of angiogenesis and endothelial cell migration.

\subsection{EVs Are Exchanged Between Maternal and Embryonic Tissues}

The human placenta releases a wide range of molecules and EVs which support the maternal physiology to adapt to fetal requirements during pregnancy $[10,19,20]$. Placenta-derived EVs (including microvesicles and exosomes) from normal human pregnancies in the first-trimester are absorbed by endothelial cells through phagocytosis and endocytosis [21]. In a mouse model, placental vesicles targeted specific organs in vivo, particularly the lungs, the liver, and the kidneys. These findings were confirmed by employing fetal cell-derived fluorescently labelled exosomes that were injected intra-amniotically into pregnant mice [9]. Exosomal trafficking and function was further demonstrated by using genetically engineered mice in which fetal and maternal exosomes could be distinguished [22]. Both feto-maternal and maternal-fetal trafficking of exosomes during pregnancy was demonstrated by this elegant approach, as exosomes from the mother were able to cross placental barriers and reach fetal tissues. The detection of fetal exosomes in maternal plasma discloses their potential as biomarkers for pregnancy monitoring using minimally invasive liquid biopsy.

\subsection{Exosomes in Pregnancy Transfer miRNAs to Regulate Gene Expression in Target Cells}

One class of small RNAs transported via extracellular vesicles, the microRNAs (miRNAs), attracted special attention. MiRNAs are post-transcriptional regulators of gene expression by inhibiting the translation of their target mRNAs or inducing mRNA degradation. It was estimated that the expression of $60 \%$ of the human genes are regulated by miRNAs [23]. The loading of miRNAs into exosomes occurs through controlled pathways [24]. MiRNAs are encoded by the genome and their transcription underlies cell program dependent regulation similar to protein coding genes. The analysis of the miRNA content in exosomes gives information about the status of the producer cell, a fact that makes them useful for diagnostic purposes. Taken up by recipient cells, the miRNAs transported by exosomes influence translation and can profoundly change the gene expression pattern. Experimental loading of exosomes with specific miRNAs is intensively explored for the transport of therapeutic nucleic acids in future therapies.

Characteristic miRNAs, which are highly expressed in human placentas, were identified in the serum of pregnant women. For instance, the concentration of placental miRNA-141 increases in maternal plasma with gestational age [25]. Several miRNAs are located in the chromosome 19 miRNA cluster (C19MC) which is the largest cluster of miRNAs in the human genome [26]. MicroRNAs within the human C19MC include 46 miRNAs which are expressed only in the placenta, the so-called placenta-associated miRNAs $[27,28]$. During pregnancy, C19MC-derived miRNAs are expressed in villous trophoblasts and secreted into the maternal circulation via exosomes where they function in placental-maternal signaling [29,30]. For instance, exosomal miR-517b increased the expression of TNF $\alpha$ and/or other death ligands [30]. The exosomal transfer of placenta-specific miR-571a-3p into NK cells repressed cGMP-dependent protein kinase 1, a key mediator of nitric oxide signaling [31]. In pregnant mice, 15 miRNAs specific for pregnant animals were identified in trophoblast-derived EVs [32]. 
Among the potential target pathways identified by bioinformatics analysis was the ubiquitin-mediated proteolysis, MAPK signaling and Focal Adhesion Pathways.

Interestingly, there is evidence that exosomes can help the fetus to avoid viral infections. Non-placental cells incubated with placental exosomes became more resistant to viral infection and this effect was mediated by the delivery of specific miRNAs [33]. Recently, another class of small RNAs have been identified in syncytiotrophoblast-derived EVs, fragments of transfer RNA (tRNA) [34]. tRNA can be split by specific enzymes into halves that exert various intracellular functions in stress signaling [35]. Transported by vesicles, tRNA halves were shown to interfere with protein synthesis in target cells [34].

\subsection{Exosomes Support the Implantation of the Embryo}

A metadata analysis of the function of extracellular vesicles in the human reproduction system suggested that they contribute to oocyte and sperm maturation, fertilization, prevention of polyspermy, and embryo implantation [36]. During the window of implantation, the embryonic blastocyst adheres to the uterus wall and initiates cell invasion. Exosomes help to establish the correct coordination between the embryo and uterine endometrium required for successful implantation [36,37]. MiRNAs have been detected as mediators of embryo-endometrium crosstalk in this process [38,39]. Exosomes released from the endometrial epithelium into the uterine cavity transfer specific miRNAs to the trophectodermal cells of the blastocyst or to endometrial epithelial cells to promote implantation [40]. Comparing the miRNAs of the exosomes and their producer cells demonstrated controlled sorting of miRNA into exosomes, and 13 of the 227 miRNA identified were specific for exosomes. Investigation of the potential pathways that are regulated by these specific exosomal miRNAs may lead to the identification of targets in pathways promoting embryo implantation [40,41]. By bioinformatics analyses, potential target genes related to ECM-receptor interactions, the Jak-Stat pathway, VEGF signaling, and Toll-like receptor signaling were identified.

Exosomes derived from human endometrial epithelial cells were shown to be taken up by trophoblasts to enhance their adhesive potential partially by enhanced focal adhesion kinase signaling [42]. In addition, in a mouse model, miRNAs present in exosomes were shown to be transferred from the receptive endometrial epithelium to embryonic trophectoderm, improving the adhesive ability of the pre-implantation embryo. Exosome-derived miR-30d could induce overexpression of genes involved in embryo adhesion, such as integrin beta-3, integrin alpha-7, and cadherin-5 [43]. A regulatory function for cell invasion was described for exosomal miR-520c-3p from chorionic villous trophoblasts. MiR-520c-3p targeted CD44 in extravillous trophoblasts, and downregulation of endogenous miR-520c-3p accelerated EVT invasion [44].

Evaluating exosomes in the uterine luminal fluid of sheep demonstrated that vesicle transported proteins could affect the implantation and fertility outcomes. Released by the endometrial epithelium, vesicles were taken up by blastocysts and the endometrium around the uterus [45]. A total of 195 vesicular proteins were identified by nano-LC-MS/MS analysis with 40 and 76 unique to the cyclic and pregnant ewes, respectively. Mass spectrometry analysis of the isolated extracellular vesicles found many proteins expressed by the endometrial epithelia and/or conceptus trophectoderm including cathepsin L1, gastrin releasing peptide, lipoprotein lipase, and prostaglandin synthase 2 [45].

\subsection{The Influence of Pregnancy-Associated EVs on the Maternal Immune System}

The fetus is antigenically distinct from the mother and therefore it is necessary to establish a tolerant immune state to prevent the rejection of the developing organism [46]. The role of exosomes released by embryonic cells and the placenta seems to be crucial for the fetus to evade the maternal immunosurveillance and destruction of the fetal 'allograft'. The immunosuppressive potential of exosomes is well recognized in cancer [47]. Cancer-derived exosomes prevent the differentiation and activation of immune effector cells, modulate antigen expression, induce $\mathrm{T}$ cell apoptosis, and transport immunosuppressive cytokines. Recently, we provided evidence that melanoma-derived EVs were 
able to confer antigen-specific immunosuppression by simultaneously transporting MHC molecules presenting cancer-specific antigenic peptides and immunosuppressive cytokines [48]. Antigen-specific immunosuppression seems to occur during pregnancy as well and could be partially mediated by EVs. Embryo-derived exosomes are taken up by cells of the maternal immune system, resulting in inhibition of the host immune system to facilitate the establishment of pregnancy, fetal development, and survival during pregnancy [49]. Exosomes derived from villous cytotrophoblasts (VCT) reduced the production of Th1 cytokines in PBMCs. Exosome-associated syncytin-2 (Syn-2), an immunosuppressive molecule, mediated this effect, as it was not observed in Syn-2-silenced VCT exosomes [50]. Most importantly, exosomes can inhibit activation of T-lymphocytes and natural killer cells that are potentially harmful to the embryo [51]. The immunosuppressive character of placenta-derived vesicles is partially mediated by the expression of death messengers including the pro-apoptotic molecules FasL (Fas ligand), PD-L1 and TRAIL [16]. Engagement of the cognate receptors triggers apoptosis in activated peripheral blood mononuclear cells (PBMCs) [52,53]. In a normal pregnancy, placental exosomes become critical in modulating T-cell activation, suppressing effector $\mathrm{T}$ cells by enhancing lymphocyte apoptosis and CD3-zeta loss [16]. CD3 loss affects the selection of T lymphocytes leading to decreased T lymphocyte-mediated responses. Embryonic exosomes also down-regulate the activating NK cell receptor NKG2D during pregnancy impairing NKG2D-mediated cytotoxicity [52,53]. NKG2D is down-regulated on NK cells by exposure to its soluble ligands [54]. The NKG2D ligands MIC-A and MIC-B are expressed by the placenta and are released via exosomes to inhibit NK cell activity.

Trophoblast-derived EVs were further shown to induce the differentiation of T cells into Treg (regulatory T) cells [55]. Treg cells exert a strong antigen-specific immunosuppression [47]. The Treg induction was mediated by HSPE1 (heat shock 10kDa protein 1) carried by the EVs [55].

In cattle, placenta-derived exosomes are abundant in the circulation of pregnant cows and exosome-derived miR-499 attenuated the expression of proinflammatory cytokines by inhibiting NF- $\mathrm{KB}$ signaling, thereby attenuating inflammatory responses and forming an immune-tolerant microenvironment in the uterus. Inhibition of miR-499 lead to inflammatory deregulation and increased risk of pregnancy failure [56].

A role in preventing the embryo from being attacked by the maternal immune system was described for glycosphingolipids (GSLs) in exosomes [57]. GSL expressing exosomes derived from villus trophoblast cells significantly induced macrophage M2 polarization during a normal pregnancy. Mature macrophages can acquire a pro-inflammatory M1 phenotype or become polarized towards an immunosuppressive M2 state [47].

Inflammation is part of an active immune response. Considering the necessity for inducing tolerance for the embryo, is might seem counterintuitive that the implantation requires a slightly inflammatory status. However, this condition does not affect the fetus directly, but facilitates tissue remodeling and embryo implantation [58]. Placental vesicles are thought to play a role in the maternal systemic inflammatory response by modulating cytokine release [59]. Exosomes isolated from pregnant women promoted the release of proinflammatory cytokines (IL-4, IL-6, IL-8, IFN- $\gamma$, TNF- $\alpha$ ) from human umbilical vein endothelial cells (HUVECs) and this effect was significantly greater when exosomes isolated from gestational diabetes mellitus (GDM) pregnancies were used [59]. In addition, macrophage-derived exosomes internalized by placental cells increased the release of pro-inflammatory cytokines such as IL-6, IL-8 and IL-10 [60].

\subsection{The Angiogenic Potential of Exosomes in Pregnancy}

Initial stages of pregnancy are characterized by spiral artery remodeling and physiological adaptations in the cardiovascular system to provide sufficient supply of nutrients and oxygen to the growing fetus [61]. Coordinated fetal vasculogenesis and maternal vascular remodeling requires invasion and differentiation of trophoblast cells. The invasive cytotrophoblasts replace the endothelial layer of the maternal spiral arteries, transforming them from high-resistance vessels into large-scale capacitance vessels suitable for sufficiently nourishing the fetus [62]. Placenta-derived EVs are reported 
to induce vasculogenesis and angiogenesis through an oxygen-sensing mechanism, especially under the hypoxic conditions during the early stages of pregnancy. Furthermore, vascular endothelial growth factor A (VEGFA), an angiogenesis stimulator and vessel growth factor, along with exosomal miRNAs, is released by the implanted embryo to regulate blood supply [63]. Both, maternal and umbilical serum exosomes enhance endothelial cell proliferation, migration, and tube formation. In umbilical serum exosomes, altered expression of a subset of migration-related miRNAs including miR-210-3p, miR-376c-3p, miR-151a-5p, miR-296-5p, miR-122-5p, and miR-550a-5p has been identified [64].

Exosomes derived from porcine trophectoderm cells induced the proliferation of the maternal endothelial cells and promoted angiogenic processes due to the presence of specific miRNAs. Increased miR-150 levels in the EVs stimulated the proliferation and migration of endothelial cells, thereby exhibiting a pro-angiogenic effect. A reduced expression of porcine miR-150 in the umbilical cord blood-derived exosomes of pigs showed intrauterine growth restriction [65]. MiRNAs involved in modulation of angiogenesis at the maternal-fetal interface were identified in porcine trophectoderm cell lines. 14 miRNAs were selectively present in CD63 positive EVs of which miR-126-5P, miR-296-5P, miR-16, and miR-17-5P were the most abundant angiogenic miRNAs [66].

\section{Exosomes in Pathological Pregnancies}

Placental exosomes are reported to be involved in the pathology of pregnancy as well $[3,67]$. The quantity and content of placental exosomes could be linked to placental dysfunction-specifically to preeclampsia, gestational diabetes, and preterm birth $[3,19,68]$. Increased secretion of vesicles was detected during pregnancies complicated by gestational diabetes [20] and preeclampsia [69]. Partially, differences in exosomal miRNA levels could be associated with these pathological states. Besides, cell-free DNA (cfDNA) of exosomal origin is considered as biomarker of pregnancy complications [70,71].

\subsection{Preeclampsia}

One of the most serious and common complications of pregnancy is preeclampsia (PE). It occurs especially in the third trimester of pregnancy. $\mathrm{PE}$ and associated hypertensive disorders are responsible for nearly $40 \%$ of premature births [72,73]. In the pathogenesis of PE, placental exosomes show variations in quantity and protein cargo, and exert some impact on maternal immune tolerance. In mouse models, EVs derived from injured placentas were shown to induce PE including hypertension and proteinuria [74]. The number of extracellular vesicles in pregnant women was tested as predictive marker for PE. The total number of microvesicles was significantly elevated in plasma obtained from women with normal pregnancy and late-onset PE compared with non-pregnant women matched by age, but there was no significant difference in pathological and normal pregnancies [75]. Shedding of vesicles and debris from trophoblast cells into the maternal circulation during PE contributed to vascular inflammation and endothelial injury, which are associated with the pathophysiology of PE [76]. Placental syncytiotrophoblast-derived extracellular vesicles contain endothelial nitric oxide synthase (eNOS), an enzyme that produces nitric oxide (NO) required for the regulation of the vascular tone and blood supply [77]. Based on diminished NO biological activity, EVs enable the prediction of pregnant disorders including PE [78]. Other studies also related low NO with placenta-derived exosomes. The exosomal miR-155, which is highly expressed in the plasma and placenta of preeclampsia patients, inhibited the expression of eNOS in endothelial cells [79]. Relevant for hypertension, EVs released by placental syncytiotrophoblasts carry neprilysin, an enzyme from the family of membrane-bound metalloproteases. Neprilysin cleaves vasopeptides, thus contributing to the establishment of hypertension, a hallmark of PE [80]. Interestingly, the rate of early onset of PE in high risk women could be significantly reduced by aspirin and this effect was mediated by down-regulation of miR-155 transported by EVs [81,82].

Both, exosomal miRNAs and proteins, were successfully employed as predictive biomarkers [83]. Small RNA sequencing of serum derived samples from women who later developed PE allowed for 
the discovery of miRNAs whose levels were deregulated in this condition [84]. The identified miRNAs were compared to the miRNAs found by 19 preceding studies pursuing similar aims. An overlap was found for 11 up-regulated and 5 down-regulated miRNAs in PE as compared to healthy pregnancies. MiR-155 was again among the up-regulated miRNAs. Furthermore, three miRNAs (miR-26b-5p, miR-7-5p, and miR-181a-5p) previously associated with hypertension, one of the hallmarks of PE, were among those deregulated in PE [84]. In another study, hsa-miR-486-1-5p and hsa-miR-486-2-5p were identified as microRNAs with predictive potential [85].

Proteomic studies identified about 400 proteins in syncytiotrophoblast EV samples with 25 proteins (including integrins, annexins, and histones) unique to PE compared to healthy pregnant controls [86]. Syncytin-2 was less abundant on the surface of serum-derived exosomes isolated from patients with PE. The levels of specific proteins in exosomes in pregnant women, such as syncytin-2, can be used as biomarkers for the prediction and diagnosis of PE [50,87]. Isolation of sub-populations of exosomes using their affinity to Cholera toxin $\mathrm{B}$ chain or annexin $\mathrm{V}$ followed by protein quantification by ELISA allowed to identify PE-predictive biomarkers. Three proteins, Tissue Inhibitor of Metalloproteinases 1 (TIMP1), Plasminogen Activator Inhibitor Type I (PAI1), and Placental Growth Factor (PlGF), showed excellent predictive robustness [88]. Furthermore, a combinatorial measurement of copeptin, Placental Growth Factor and Annexin V-positive microparticles could be used for PE prediction and discrimination from other pregnancy complications [89]

\subsection{Pre-Tterm Birth}

According to the World Health Organization, an estimated 15 million infants are born too early each year [90]. Complications following preterm birth are the leading cause of death among children under five years of age and are responsible for about one million deaths each year globally. A pre-term birth in humans is defined as birth before 37 completed weeks of gestation. PE is one of the major medical causes of pre-term birth.

In pregnant mice, the concentration of exosomes was significantly lower in preterm birth induced by inflammation compared to animals with normal delivery [91]. Pathway analysis after determination of exosomal protein profiles at term and preterm birth pointed at changes in inflammatory and endocrine signaling, which might disrupt pregnancy maintenance [92]. To test the influence of exosome signaling on parturition timing, vesicles were isolated from the blood of pregnant mice either during early or late pregnancy. Then, these EVs were injected into a separate group of pregnant mice in a pregnancy stage corresponding to the beginning of the third trimester in human [93]. The injection of a high concentration of late pregnancy exosomes was able to cause labor-associated changes without the other hormonal and chemical triggers usually involved in this process. In contrary, the injections of the early pregnancy exosomes had no effect [93].

A range of miRNAs isolated from maternal plasma were described as predictive biomarkers for pre-term birth, however, whether these miRNAs were transported by EVs was not evaluated in these studies [94-97]. Identification of miRNAs transported by EVs also revealed potential biomarkers for the prediction of pre-term birth [98]. Changes of the protein composition of circulating placental EVs could also be used for the identification of a high-risk status for pre-term birth across gestation [99]. Ninety-six proteins were expressed at significantly different levels, and a bioinformatics analysis revealed their connection to inflammatory pathways, epithelial mesenchymal transition, and coagulation/complement activation.

\subsection{Gestational Diabetes Mellitus (GDM)}

Another important complication of pregnancy, which can harm both the fetus and the mother, is gestational diabetes mellitus (GDM). During normal pregnancy, at the time of the second and third trimester, limited insulin resistance gradually increases as a normal phenomenon to ensure sufficient nutrient supply for the fetus. A pregnant mother with pathologic insulin resistance-acquired or chronic-is not able to compensate for the increased circulating glucose concentrations because of $\beta$-cell 
dysfunction. As a result, maternal hyperglycemia occurs, leading to increased risk of disease for both the mother and the fetus [100]. GDM is defined by any degree of abnormal glucose metabolism diagnosed during pregnancy and/or glucose intolerance that was not present or recognized before pregnancy. GDM associated hyperglycemia, hyperinsulinemia, and hypoxia may adversely affect the maternal-fetal vascular exchange and placentation, leading to preterm birth, fetal distress, fetal death, and other adverse pregnancy outcomes. GDM was associated with elevated levels of exosomes in the maternal circulation. Placental exosomes from GDM pregnancies decreased insulin-stimulated migration and glucose uptake in primary skeletal muscle cells obtained from patients with normal insulin sensitivity. In contrary, the exosomes derived from normal glucose tolerant patients increased the glucose uptake in response to insulin in skeletal muscle cells from diabetic subjects [101]. A connection between increased exosome levels and glucose concentration in GDM was also described in first-trimester trophoblast cells inducing the release of cytokines from endothelial cells [102]. It was suggested that increased placental glycogenolysis in GDM accelerates glucose transfer to the fetus, resulting in fetal overgrowth. There is a significant association between high body weight and diabetes, and adipose tissue-derived exosomes were shown to influence the placental glycogenolysis. Pathway analysis of exosomal proteins revealed differential expression of mitochondrial function-related proteins in adipose tissue-derived exosomes of GDM [103].

A proteomic study identified 78 proteins with significantly altered levels in GDM-derived exosomes compared to normal ones. Pathway analysis revealed that many of these proteins are involved in energy production and inflammation [104]. Analysis of urinary exosomes revealed that the damage associated molecular pattern (DAMP) protein S100A9 was present at higher levels in exosomes in GDM and could be used as valid biomarker of inflammatory processes and immune responses [105]. In addition, increased levels of miRNA members of the C19MC region were found in exosomes during GDM: miR-518a-5p, miR-518b, miR-518c, miR-518e, miR-520c-3p, and miR-525-5p [106,107]. Furthermore, the expression of specific exosomal miRs including miR-125a-3p, miR-99b-5p, miR-197-3p, miR-22-3p, and miR-224-5p were detected at elevated levels in the placenta, in circulating exosomes and in skeletal muscle in GDM [101]. Several studies analyzed the miRNA changes in GDM in plasma samples without isolating EVs [108-110]. All of them identified candidates suitable for GDM prediction. The usage of exosomes to treat GDM was suggested recently [111].

\section{Conclusions}

The contribution of exosomes in fetal-maternal communication during pregnancy has been firmly established (Figure 3). It is even conceivable that exosomes are necessary for the successful implantation of the embryo and its normal development. Despite growing interest in elucidating the role of exosomes during normal and complicated pregnancies, progress in the field seems to be quite slow. One of the reasons may be connected to problems with the isolation of placental exosomes from the maternal circulation. An improved workflow for their isolation was recently described [112,113]. Changes in exosomal concentration, composition, and/or their bioactivity, such as interaction with maternal cells, may participate in the development of pathological states, and exosomes can be used as biomarkers in the prediction of pregnancy complications such as preeclampsia, fetal growth restriction, and preterm birth $[29,114-116]$. Furthermore, exosomes have the potential to serve as new therapeutic targets in infertility [117]. The unique characteristics of exosomes and their ability to carry cargo to distant destinations in the body makes them ideal candidates to signal between feto-maternal tissues during pregnancy [15]. Studying the contribution of exosomes in pathological pregnancies and related diseases, such as infertility or pregnancy failure can open the way for new exosome-based therapies [118]. 


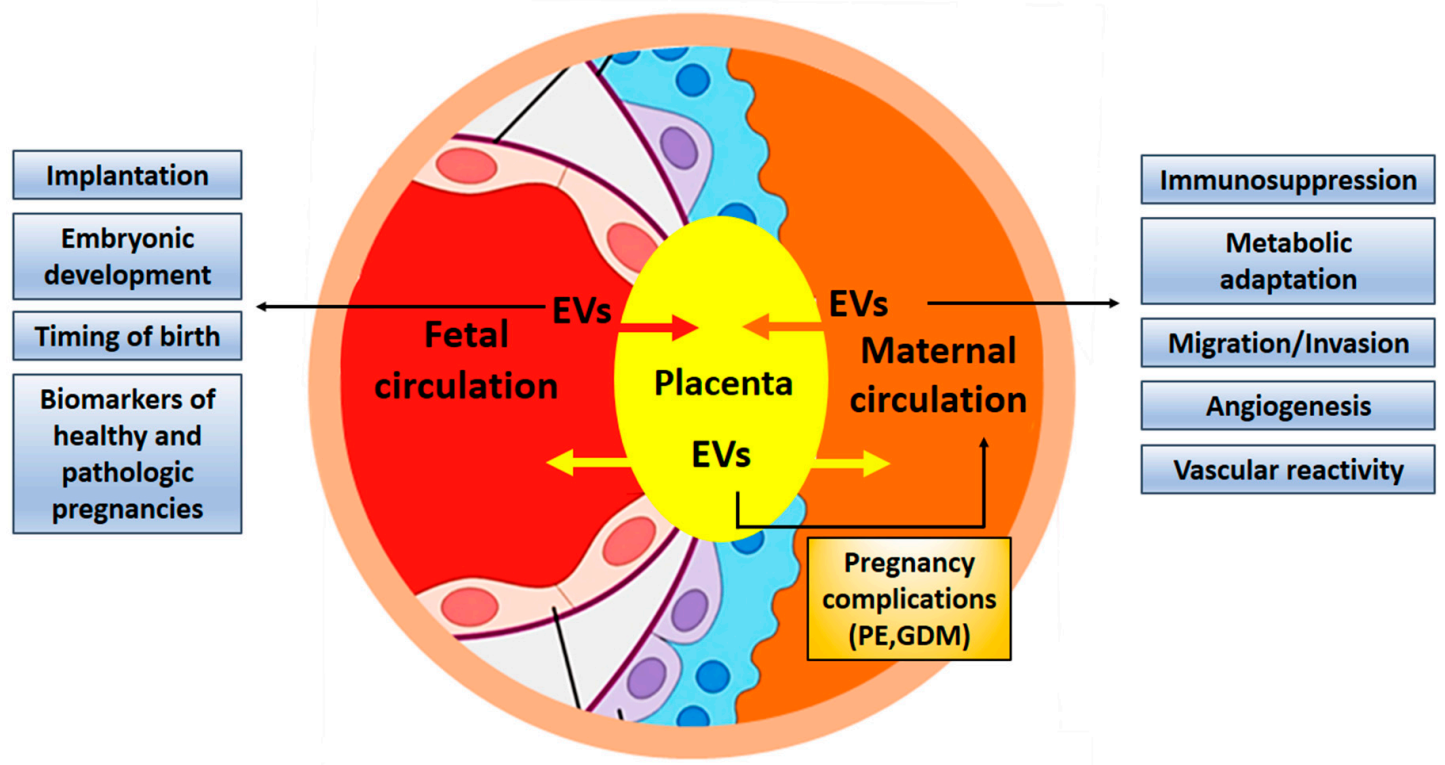

Figure 3. Exosomes contribute to fetal-maternal communication. Exosomes are exchanged between maternal and embryonic tissues to facilitate implantation and development of the embryo, adapting the maternal organism for pregnancy by suppressing immune responses and guaranteeing nutritional supply. Exosomes can also contribute to pregnancy complications and might be used as biomarkers. EV, extracellular vesicles; PE, preeclampsia; GDM, gestational diabetes mellitus.

Author Contributions: Conceptualization-L.C. and M.D.; writing-original draft preparation, L.C.; writing-review and editing, M.D.; supervision, M.D.; funding acquisition, M.D. All authors have read and agreed to the published version of the manuscript.

Funding: This research was funded by the National Science Centre of Poland (NCN, Poland), grant number 2016/21/B/NZ7/02747, as well as by statutory funds of the Centre of Molecular and Macromolecular Studies of the Polish Academy of Sciences.

Conflicts of Interest: The authors declare no conflict of interest.

\section{Abbreviations}

EV extracellular vesicle

CT cytotrophoblast

VCT villous cytotrophoblasts

SCT syncytiotrophoblast

PLAP placental alkaline phosphatase

HLA-G human leukocyte antigen $G$

MSC mesenchymal stem cells

C19MC chromosome 19 miRNA cluster

TNF $\alpha$ tumor necrosis factor $\alpha$

ECM extra-cellular matrix

VEGF vascular endothelial growth factor

EVT extravillous trophoblast

LC-MS liquid chromatography-mass spectrometry

FasL Fas ligand

PD-L1 programmed death ligand-1

TRAIL TNF- Related Apoptosis Inducing Ligand

PBMCs peripheral blood mononuclear cells

HSPE1 heat shock 10kDa protein 1

GSL glycosphingolipid

IL-4 interleukin-4 


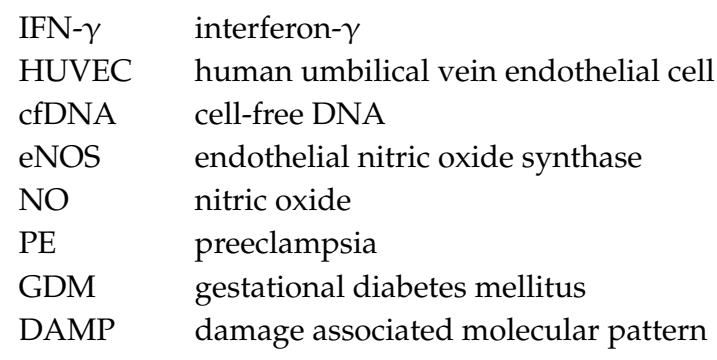

\section{References}

1. McNanley, T.; Woods, J. Placental Physiology. Glob. Libr. Women's Med. 2008. [CrossRef]

2. Linzer, D.I.; Fisher, S.J. The placenta and the prolactin family of hormones: Regulation of the physiology of pregnancy. Mol. Endocrinol. 1999, 13, 837-840. [CrossRef] [PubMed]

3. Jin, J.; Menon, R. Placental exosomes: A proxy to understand pregnancy complications. Am. J. Reprod. Immunol. 2018, 79, e12788. [CrossRef] [PubMed]

4. Rai, R.; Regan, L. Recurrent miscarriage. Lancet 2006, 368, 601-611. [CrossRef]

5. van der Pol, E.; Böing, A.N.; Harrison, P.; Sturk, A.; Nieuwland, R. Classification, functions, and clinical relevance of extracellular vesicles. Pharmacol. Rev. 2012, 3, 676-705. [CrossRef]

6. Willms, E.; Johansson, H.J.; Mäger, I.; Lee, Y.; Blomberg, K.E.M.; Sadik, M.; Alaarg, A.; Smith, C.I.E.; Lehtiö, J.; Andaloussi, S.E.L.; et al. Cells release subpopulations of exosomes with distinct molecular and biological properties. Sci. Rep. 2016, 6, 22519. [CrossRef]

7. György, B.; Szabó, T.G.; Pásztói, M.; Pál, Z.; Misják, P.; Aradi, B.; László, V.; Pállinger, E.; Pap, E.; Kittel, A.; et al. Membrane vesicles, current state-of-the-art: Emerging role of extracellular vesicles. Cell. Mol. Life Sci. 2011, 68, 2667-2688. [CrossRef]

8. Ochoa-Bernal, M.A.; Fazleabas, A.T. Physiologic Events of Embryo Implantation and Decidualization in Human and Non-Human Primates. Int. J. Mol. Sci. 2020, 21, 1973. [CrossRef]

9. Sheller-Miller, S.; Lei, J.; Saade, G.; Salomon, C.; Burd, I.; Menon, R. Feto-Maternal Trafficking of Exosomes in Murine Pregnancy Models. Front. Pharmacol. 2016, 7, 432. [CrossRef]

10. Tannetta, D.; Masliukaite, I.; Vatish, M.; Redman, C.; Sargent, I. Update of syncytiotrophoblast derived extracellular vesicles in normal pregnancy and preeclampsia. J. Reprod. Immunol. 2017, 119, 98-106. [CrossRef]

11. Kshirsagar, S.K.; Alam, S.M.; Jasti, S.; Hodes, H.; Nauser, T.; Gilliam, M.; Billstrand, C.; Hunt, J.S.; Petroff, M.G. Immunomodulatory molecules are released from the first trimester and term placenta via exosomes. Placenta 2012, 33, 982-990. [CrossRef]

12. Miranda, J.; Paules, C.; Nair, S.; Lai, A.; Palma, C.; Scholz-Romero, K.; Rice, G.E.; Gratacos, E.; Crispi, F.; Salomon, C. Placental exosomes profile in maternal and fetal circulation in intrauterine growth restriction-Liquid biopsies to monitoring fetal growth. Placenta 2018, 64, 34-43. [CrossRef] [PubMed]

13. Schwartz-Bloom, R.D.; Crews, F.T.; Porrino, L.J.; Friedman, D.P.; Morrow, A.L.; Sulik, K.K. The Alcohol Pharmacology Education Partnership-Module 5. Available online: https://sites.duke.edu/apep/module-5alcohol-and-babies (accessed on 1 June 2020).

14. Albrecht, C.; Institute of Biochemistry and Molecular Medicine, University of Bern. Available online: https://www.ibmm.unibe.ch/research/group_albrecht/index_eng.html (accessed on 1 June 2020).

15. Menon, R.; Mesiano, S.; Taylor, R.N. Programmed fetal membrane senescence and exosome-mediated signaling: A mechanism associated with timing of human parturition. Front. Endocrinol. 2017, 8, 196. [CrossRef]

16. Sabapatha, A.; Gercel-Taylor, C.; Taylor, D.D. Specific isolation of placenta-derived exosomes from the circulation of pregnant women and their immunoregulatory consequences. Am. J. Reprod. Immunol. 2006, 56, 345-355. [CrossRef] [PubMed]

17. Sarker, S.; Scholz-Romero, K.; Perez, A.; Illanes, S.E.; Mitchell, M.D.; Rice, G.E.; Salomon, C. Placenta-derived exosomes continuously increase in maternal circulation over the first trimester of pregnancy. Transl. Med. 2014, 12, 204. [CrossRef] [PubMed] 
18. Salomon, C.; Kobayashi, M.; Ashman, K.; Sobrevia, L.; Mitchell, M.D.; Rice, G.E. Hypoxia-induced changes in the bioactivity of cytotrophoblast-derived exosomes. PLoS ONE 2013, 8, e79636. [CrossRef] [PubMed]

19. Mitchell, M.D.; Peiris, H.N.; Kobayashi, M.; Koh, Y.Q.; Duncombe, G.; Illanes, S.E.; Rice, G.E.; Salomon, C. Placental exosomes in normal and complicated pregnancy. Am. J. Obstet. Gynecol. 2015, 213, S173-S181. [CrossRef]

20. Salomon, C.; Torres, M.J.; Kobayashi, M.; Scholz-Romero, K.; Sobrevia, L.; Dobierzewska, A.; Illanes, S.E.; Mitchell, M.D.; Rice, G.E. A gestational profile of placental exosomes in maternal plasma and their effects on endothelial cell migration. PLoS ONE 2014, 9, e98667. [CrossRef]

21. Tong, M.; Chen, Q.; James, J.L.; Wise, M.R.; Stone, P.R.; Chamley, L.W. In vivo targets of human placental micro-vesicles vary with exposure time and pregnancy. Reproduction 2017, 153, 835-845. [CrossRef]

22. Sheller-Miller, S.; Choi, K.; Choi, C.; Menon, R. Cyclic-recombinase-reporter mouse model to determine exosome communication and function during pregnancy. Am. J. Obstet. Gynecol. 2019, 221, 502. [CrossRef]

23. Sayed, D.; Abdellatif, M. MicroRNAs in development and disease. Physiol. Rev. 2011, 91, 827-887. [CrossRef] [PubMed]

24. Kluszczyńska, K.; Czernek, L.; Cypryk, W.; Pęczek, Ł.; Düchler, M. Methods for the Determination of the Purity of Exosomes. Curr. Pharm. Des. 2019, 25, 4464-4485. [CrossRef] [PubMed]

25. Chim, S.S.; Shing, T.K.; Hung, E.C.; Leung, T.Y.; Lau, T.K.; Chiu, R.W.; Lo, Y.M. Detection and characterization of placental microRNAs in maternal plasma. Clin. Chem. 2008, 54, 482-490. [CrossRef] [PubMed]

26. Ouyang, Y.; Mouillet, J.F.; Coyne, C.B.; Sadovsky, Y. Review: Placenta-specific microRNAs in exosomes-good things come in nano-packages. Placenta 2014, 35, S69-S73. [CrossRef] [PubMed]

27. Noguer-Dance, M.; Abu-Amero, S.; Al-Khtib, M.; Lefèvre, A.; Coullin, P.; Moore, G.E.; Cavaillé, J. The primate-specific microRNA gene cluster (C19MC) is imprinted in the placenta. Hum. Mol. Genet. 2010, 19, 3566-3582. [CrossRef] [PubMed]

28. Yuan, Z.; Sun, X.; Jiang, D.; Ding, Y.; Lu, Z.; Gong, L.; Liu, H.; Xie, J. Origin and evolution of a placental-specific microRNA family in the human genome. BMC Evol. Biol. 2010, 10, 346. [CrossRef]

29. Donker, R.B.; Mouillet, J.F.; Chu, T.; Hubel, C.A.; Stolz, D.B.; Morelli, A.E.; Sadovsky, Y. The expression profile of C19MC microRNAs in primary human trophoblast cells and exosomes. Mol. Hum. Reprod. 2012, 18, 417-424. [CrossRef]

30. Luo, S.S.; Ishibashi, O.; Ishikawa, G.; Ishikawa, T.; Katayama, A.; Mishima, T.; Takizawa, T.; Shigihara, T.; Goto, T.; Izumi, A.; et al. Human villous trophoblasts express and secrete placenta-specific microRNAs into maternal circulation via exosomes. Biol. Reprod. 2009, 81, 717-729. [CrossRef]

31. Kambe, S.; Yoshitake, H.; Yuge, K.; Ishida, Y.; Ali, M.M.; Takizawa, T.; Kuwata, T.; Ohkuchi, A.; Matsubara, S.; Suzuki, M.; et al. Human exosomal placenta-associated miR-517a-3p modulates the expression of PRKG1 mRNA in Jurkat cells. Biol. Reprod. 2014, 91, 129. [CrossRef]

32. Stefanski, A.L.; Martinez, N.; Peterson, L.K.; Callahan, T.J.; Treacy, E.; Luck, M.; Friend, S.F.; Hermesch, A.; Maltepe, E.; Phang, T.; et al. Murine trophoblast-derived and pregnancy-associated exosome-enriched extracellular vesicle microRNAs: Implications for placenta driven effects on maternal physiology. PLoS ONE 2019, 14, e0210675. [CrossRef]

33. Delorme-Axford, E.; Donker, R.B.; Mouillet, J.F.; Chu, T.; Bayer, A.; Ouyang, Y.; Wang, T.; Stolz, D.B.; Sarkar, S.N.; Morelli, A.E.; et al. Human placental trophoblasts confer viral resistance to recipient cells. Proc. Natl. Acad. Sci. USA 2013, 110, 12048-12053. [CrossRef] [PubMed]

34. Cooke, W.R.; Cribbs, A.; Zhang, W.; Kandzija, N.; Motta-Mejia, C.; Dombi, E.; Ri, R.; Cerdeira, A.S.; Redman, C.; Vatish, M. Maternal circulating syncytiotrophoblast-derived extracellular vesicles contain biologically active 5'-tRNA halves. Biochem. Biophys. Res. Commun. 2019, 518, 107-113. [CrossRef] [PubMed]

35. Nawrot, B.; Sochacka, E.; Düchler, M. tRNA structural and functional changes induced by oxidative stress. Cell. Mol. Life Sci. 2011, 68, 4023-4032. [CrossRef] [PubMed]

36. Machtinger, R.; Laurent, L.C.; Baccarelli, A.A. Extracellular vesicles: Roles in gamete maturation, fertilization and embryo implantation. Hum. Reprod. Update 2016, 22, 182-193. [CrossRef]

37. Nakamura, K.; Kusama, K.; Bai, R.; Sakurai, T.; Isuzugawa, K.; Godkin, J.D.; Suda, Y.; Imakawa, K. Induction of IFNT-Stimulated Genes by Conceptus-Derived Exosomes during the Attachment Period. PLoS ONE 2016, 11, e0158278. [CrossRef]

38. Hemmatzadeh, M.; Shomali, N.; Yousefzadeh, Y.; Mohammadi, H.; Ghasemzadeh, A.; Yousefi, M. MicroRNAs: Small molecules with a large impact on pre-eclampsia. J. Cell. Physiol. 2019, 235, 3235-3248. [CrossRef] 
39. Chang, G.; Mouillet, J.F.; Mishima, T.; Chu, T.; Sadovsky, E.; Coyne, C.B.; Parks, W.T.; Surti, U.; Sadovsky, Y. Expression and trafficking of placental microRNAs at the feto-maternal interface. FASEB J. 2017, 31, 2760-2770. [CrossRef]

40. Ng, Y.H.; Rome, S.; Jalabert, A.; Forterre, A.; Singh, H.; Hincks, C.L.; Salamonsen, L.A. Endometrial exosomes/microvesicles in the uterine microenvironment: A new paradigm for embryo-endometrial cross talk at implantation. PLoS ONE 2013, 8, e58502. [CrossRef]

41. Sullivan, R.; Saez, F. Epididymosomes, prostasomes, and liposomes: Their roles in mammalian male reproductive physiology. Reproduction 2013, 146, R21-R35. [CrossRef]

42. Greening, D.W.; Nguyen, H.P.; Elgass, K.; Simpson, R.J.; Salamonsen, L.A. Human Endometrial Exosomes Contain Hormone-Specific Cargo Modulating Trophoblast Adhesive Capacity: Insights into Endometrial-Embryo Interactions. Biol. Reprod. 2016, 94, 38. [CrossRef]

43. Vilella, F.; Moreno-Moya, J.M.; Balaguer, N.; Grasso, A.; Herrero, M.; Martínez, S.; Marcilla, A.; Simón, C. Hsa-mir-30d, secreted by the human endometrium, is taken up by the pre-implantation embryo and might modify its transcriptome. Development 2015, 142, 3210-3221. [CrossRef] [PubMed]

44. Takahashi, H.; Ohkuchi, A.; Kuwata, T.; Usui, R.; Baba, Y.; Suzuki, H.; Chaw Kyi, T.T.; Matsubara, S.; Saito, S.; Takizawa, T. Endogenous and exogenous miR-520c-3p modulates CD44-mediated extravillous trophoblast invasion. Placenta 2017, 50, 25-31. [CrossRef] [PubMed]

45. Burns, G.; Brooks, K.; Wildung, M.; Navakanitworakul, R.; Christenson, L.K.; Spencer, T.E. Extracellular vesicles in luminal fluid of the ovine uterus. PLoS ONE 2014, 9, e90913. [CrossRef]

46. Aluvihare, V.R.; Kallikourdis, M.; Betz, A.G. Tolerance, suppression and the fetal allograft. J. Mol. Med. 2005, 83, 88-96. [CrossRef] [PubMed]

47. Czernek, L.; Düchler, M. Functions of Cancer-Derived Extracellular Vesicles in Immunosuppression. Arch. Immunol. Ther. Exp. (Warsz.) 2017, 65, 311-323. [CrossRef]

48. Düchler, M.; Czernek, L.; Peczek, L.; Cypryk, W.; Sztiller-Sikorska, M.; Czyz, M. Melanoma-Derived Extracellular Vesicles Bear the Potential for the Induction of Antigen-Specific Tolerance. Cells 2019, 8, 665. [CrossRef]

49. Kaminski, V.L.; Ellwanger, J.H.; Chies, J.A.B. Extracellular vesicles in host-pathogen interactions and immune regulation-exosomes as emerging actors in the immunological theater of pregnancy. Heliyon 2019, 5, e02355. [CrossRef]

50. Lokossou, A.G.; Toudic, C.; Nguyen, P.T.; Elisseeff, X.; Vargas, A.; Rassart, É.; Lafond, J.; Leduc, L.; Bourgault, S.; Gilbert, C.; et al. Endogenous retrovirus-encoded syncytin-2 contributes to exosome-mediated immunosuppression of $\mathrm{t}$ cells. Biol. Reprod. 2020, 102, 185-198. [CrossRef]

51. Mincheva-Nilsson, L.; Baranov, V. Placenta-derived exosomes and syncytiotrophoblast microparticles and their role in human reproduction: Immune modulation for pregnancy success. Am. J. Reprod. Immunol. 2014, 72, 440-457. [CrossRef]

52. Stenqvist, A.C.; Nagaeva, O.; Baranov, V.; Mincheva-Nilsson, L. Exosomes secreted by human placenta carry functional fas ligand and trail molecules and convey apoptosis in activated immune cells, suggesting exosome-mediated immune privilege of the fetus. J. Immunol. 2013, 191, 5515-5523. [CrossRef]

53. Mincheva-Nilsson, L.; Nagaeva, O.; Chen, T.; Stendahl, U.; Antsiferova, J.; Mogren, I.; Hernestål, J.; Baranov, V. Placenta-derived soluble MHC class I, chain-related molecules down-regulate NKG2D receptor on peripheral blood mononuclear cells during human pregnancy: A possible novel immune escape mechanism for fetal survival. J. Immunol. 2006, 176, 3585-3592. [CrossRef] [PubMed]

54. Huang, S.Y.; Chiang, C.H.; Chen, F.P.; Yu, C.L. The alteration of placental-derived soluble MHC class I chain-related protein A and B during pregnancy. Acta. Obstet. Gynecol. Scand. 2011, 90, 802-807. [CrossRef] [PubMed]

55. Kovács, Á.F.; Fekete, N.; Turiák, L.; Ács, A.; Kőhidai, L.; Buzás, E.I.; Pállinger, É. Unravelling the Role of Trophoblastic-Derived Extracellular Vesicles in Regulatory T Cell Differentiation. Int. J. Mol. Sci. 2019, 20, 3457. [CrossRef] [PubMed]

56. Zhao, G.; Yang, C.; Yang, J.; Liu, P.; Jiang, K.; Shaukat, A.; Wu, H.; Deng, G. Placental exosome-mediated bta-mir-499-lin28b/let-7 axis regulates inflammatory bias during early pregnancy. Cell Death Dis. 2018, 9, 704. [CrossRef] [PubMed]

57. $\mathrm{Wu}, \mathrm{H}$. Roles of exosome-associated glycosphingolipids in immune tolerance of embryo implantation and pregnancy. Fertil. Steril. 2018, 110, e238. [CrossRef] 
58. Mor, G.; Cardenas, I.; Abrahams, V.; Guller, S. Inflammation and pregnancy: The role of the immune system at the implantation site. Ann. N. Y. Acad. Sci. 2011, 1221, 80-87. [CrossRef] [PubMed]

59. Salomon, C.; Scholz-Romero, K.; Sarker, S.; Sweeney, E.; Kobayashi, M.; Correa, P.; Longo, S.; Duncombe, G.; Mitchell, M.D.; Rice, G.E.; et al. Gestational Diabetes Mellitus Is Associated With Changes in the Concentration and Bioactivity of Placenta-Derived Exosomes in Maternal Circulation Across Gestation. Diabetes 2016, 65, 598-609. [CrossRef]

60. Holder, B.; Jones, T.; Sancho Shimizu, V.; Rice, T.F.; Donaldson, B.; Bouqueau, M.; Forbes, K.; Kampmann, B. Macrophage exosomes induce placental inflammatory cytokines: A novel mode of maternal-placental messaging. Traffic 2016, 17, 168-178. [CrossRef]

61. Sanghavi, M.; Rutherford, J.D. Cardiovascular physiology of pregnancy. Circulation 2014, 130, $1003-1008$. [CrossRef]

62. Massimiani, M.; Vecchione, L.; Piccirilli, D.; Spitalieri, P.; Amati, F.; Salvi, S.; Ferrazzani, S.; Stuhlmann, H.; Campagnolo, L. Epidermal growth factor-like domain 7 promotes migration and invasion of human trophoblast cells through activation of MAPK, PI3K and NOTCH signaling pathways. Mol. Hum. Reprod. 2015, 21, 435-451. [CrossRef]

63. Patton, A.L.; McCallie, B.; Parks, J.C.; Schoolcraft, W.B.; Katz-Jaffe, M. Exosome bound microRNAs transcriptionally regulate embryo-endometrial dialogue impacting implantation potential for AMA patients. Fertil. Steril. 2015, 104, e308. [CrossRef]

64. Jia, L.; Zhou, X.; Huang, X.; Xu, X.; Jia, Y.; Wu, Y.; Yao, J.; Wu, Y.; Wang, K. Maternal and umbilical cord serum-derived exosomes enhance endothelial cell proliferation and migration. FASEB J. 2018, 32, 4534-4543. [CrossRef] [PubMed]

65. Luo, J.; Fan, Y.; Shen, L.; Niu, L.; Zhao, Y.; Jiang, D.; Zhu, L.; Jiang, A.; Tang, Q.; Ma, J.; et al. The pro-angiogenesis of exosomes derived from umbilical cord blood of intrauterine growth restriction pigs was repressed associated with miRNAs. Int. J. Biol. Sci. 2018, 14, 1426-1436. [CrossRef] [PubMed]

66. Bidarimath, M.; Khalaj, K.; Kridli, R.T.; Kan, F.W.; Koti, M.; Tayade, C. Extracellular vesicle mediated intercellular communication at the porcine maternal-fetal interface: A new paradigm for conceptus-endometrial cross-talk. Sci. Rep. 2017, 7, 40476. [CrossRef]

67. van der Post, J.A.; Lok, C.A.; Boer, K.; Sturk, A.; Sargent, I.L.; Nieuwland, R. The functions of microparticles in pre-eclampsia. Semin. Thromb. Hemost. 2011, 37, 146-152. [CrossRef]

68. Yang, C.; Song, G.; Lim, W. Effects of extracellular vesicles on placentation and pregnancy disorders. Reproduction 2019, 158, R189-R196. [CrossRef]

69. Tannetta, D.S.; Dragovic, R.A.; Gardiner, C.; Redman, C.W.; Sargent, I.L. Characterisation of syncytiotrophoblast vesicles in normal pregnancy and pre-eclampsia: Expression of Flt-1 and endoglin. PLOS ONE 2013, 8, e56754. [CrossRef]

70. Repiská, G.; Konečná, B.; Shelke, G.V.; Lässer, C.; Vlková, B.I.; Minárik, G.F.F. Is the DNA of placental origin packaged in exosomes isolated from plasma and serum of pregnant women? Clin. Chem. Lab. Med. 2018, 56, e150-e153. [CrossRef]

71. Konečná, B.; Tóthová, L.; Repiská, G. Exosomes-Associated DNA-New Marker in Pregnancy Complications? Int. J. Mol. Sci. 2019, 20, 2890. [CrossRef]

72. Ananth, C.V.; Keyes, K.M.; Wapner, R.J. Pre-eclampsia rates in the United States, 1980-2010: Age-period-cohort analysis. BMJ 2013, 347, f6564. [CrossRef]

73. Kuklina, E.V.; Ayala, C.; Callaghan, W.M. Hypertensive disorders and severe obstetric morbidity in the United States. Obstet. Gynecol. 2009, 113, 1299-1306. [CrossRef] [PubMed]

74. Han, C.; Wang, C.; Chen, Y.; Wang, J.; Xu, X.; Hilton, T.; Cai, W.; Zhao, Z.; Wu, Y.; Li, K.; et al. Placenta-derived extracellular vesicles induce preeclampsia in mouse models. Haematologica 2020, 105, 1686-1694. [CrossRef] [PubMed]

75. Dragovic, R.A.; Southcombe, J.H.; Tannetta, D.S.; Redman, C.W.; Sargent, I.L. Multicolor flow cytometry and nanoparticle tracking analysis of extracellular vesicles in the plasma of normal pregnant and pre-eclamptic women. Biol. Reprod. 2013, 89, 151. [CrossRef] [PubMed]

76. Redman, C.W.; Tannetta, D.S.; Dragovic, R.A.; Gardine, C.; Southcombe, J.H.; Collett, G.P.; Sargent, I.L. Does size matter? Placental debris and the pathophysiology of pre-eclampsia. Placenta 2012, 33, S48-S54. [CrossRef] [PubMed] 
77. Gaynullina, D.K.; Schubert, R.; Tarasova, O.S. Changes in Endothelial Nitric Oxide Production in Systemic Vessels during Early Ontogenesis-A Key Mechanism for the Perinatal Adaptation of the Circulatory System. Int. J. Mol. Sci. 2019, 20, 1421. [CrossRef] [PubMed]

78. Motta-Mejia, C.; Kandzija, N.; Zhang, W.; Mhlomi, V.; Cerdeira, A.S.; Burdujan, A.; Tannetta, D.; Dragovic, R.; Sargent, I.L.; Redman, C.W.; et al. Placental Vesicles Carry Active Endothelial Nitric Oxide Synthase and Their Activity is Reduced in Preeclampsia. Hypertension 2017, 70, 372-381. [CrossRef]

79. Shen, L.; Li, Y.; Li, R.; Diao, Z.; Yany, M.; Wu, M.; Sun, H.; Yan, G.; Hu, Y. Placenta associated serum exosomal miR155 derived from patients with preeclampsia inhibits eNOS expression in human umbilical vein endothelial cells. Int. J. Mol. Med. 2018, 41, 1731-1739.

80. Gill, M.; Motta-Mejia, C.; Kandzija, N.; Cooke, W.; Zhang, W.; Cerdeira, A.S.; Bastie, C.; Redman, C.; Vatish, M. Placental Syncytiotrophoblast-Derived Extracellular Vesicles Carry Active NEP (Neprilysin) and Are Increased in Preeclampsia. Hypertension 2019, 73, 1112-1119. [CrossRef]

81. Dutta, S.; Kumar, S.; Hyett, J.; Salomon, C. Molecular Targets of Aspirin and Prevention of Preeclampsia and Their Potential Association with Circulating Extracellular Vesicles during Pregnancy. Int. J. Mol. Sci. 2019, 20, 4370. [CrossRef]

82. Kim, J.; Lee, K.S.; Kim, J.H.; Lee, D.K.; Park, M.; Choi, S.; Park, W.; Kim, S.; Choi, Y.K.; Hwang, J.Y.; et al. Aspirin prevents TNF-a-induced endothelial cell dysfunction by regulating the NF-kB-dependent miR-155/eNOS pathway: Role of a miR-155/eNOS axis in preeclampsia. Free Radic Biol. Med. 2017, 104, 185-198. [CrossRef]

83. Hromadnikova, I.; Dvorakova, L.; Kotlabova, K.; Krofta, L. The Prediction of Gestational Hypertension, Preeclampsia and Fetal Growth Restriction via the First Trimester Screening of Plasma Exosomal C19MC microRNAs. Int. J. Mol. Sci. 2019, 20, 2972. [CrossRef] [PubMed]

84. Srinivasan, S.; Treacy, R.; Herrero, T.; Olsen, R.; Leonardo, T.R.; Zhang, X.; DeHoff, P.; To, C.; Poling, L.G.; Fernando, A.; et al. Discovery and Verification of Extracellular miRNA Biomarkers for Non-invasive Prediction of Pre-eclampsia in Asymptomatic Women. Cell Rep. Med. 2020, 1, 100013. [CrossRef]

85. Salomon, C.; Guanzon, D.; Scholz-Romero, K.; Longo, S.; Correa, P.; Illanes, S.E.; Rice, G.E. Placental Exosomes as Early Biomarker of Preeclampsia: Potential Role of Exosomal MicroRNAs Across Gestation. J. Clin. Endocrinol. Metab. 2017, 102, 3182-3194. [CrossRef] [PubMed]

86. Baig, S.; Kothandaraman, N.; Manikandan, J.; Rong, L.; Ee, K.H.; Hill, J.; Lai, C.W.; Tan, W.Y.; Yeoh, F.; Kale, A.; et al. Proteomic analysis of human placental syncytiotrophoblast microvesicles in preeclampsia. Clin. Proteom. 2014, 11, 40. [CrossRef] [PubMed]

87. Vargas, A.; Zhou, S.; Éthier-Chiasson, M.; Flipo, D.; Lafond, J.; Gilbert, C.; Barbeau, B. Syncytin proteins incorporated in placenta exosomes are important for cell uptake and show variation in abundance in serum exosomes from patients with preeclampsia. FASEB J. 2014, 28, 3703-3719. [CrossRef]

88. Tan, K.H.; Tan, S.S.; Ng, M.J.; Tey, W.S.; Sim, W.K.; Allen, J.C.; Lim, S.K. Extracellular vesicles yield predictive pre-eclampsia biomarkers. J. Extracell. Vesicles 2017, 6, 1408390. [CrossRef] [PubMed]

89. Jadli, A.; Ghosh, K.; Satoskar, P.; Damania, K.; Bansal, V.; Shetty, S. Combination of copeptin, placental growth factor and total annexin $\mathrm{V}$ microparticles for prediction of preeclampsia at 10-14 weeks of gestation. Placenta 2017, 58, 67-73. [CrossRef]

90. Klumper, J.; Breebaart, W.; Roos, C.; Naaktgeboren, C.A.; van der Post, J.; Bosmans, J.; van Kaam, A.; Schuit, E.; Mol, B.W.; Baalman, J.; et al. Study protocol for a randomised trial for atosiban versus placebo in threatened preterm birth: The APOSTEL 8 study. BMJ Open 2019, 9, e029101. [CrossRef]

91. Nguyen, S.L.; Greenberg, J.W.; Wang, H.; Collaer, B.W.; Wang, J.; Petroff, M.G. Quantifying murine placental extracellular vesicles across gestation and in preterm birth data with tidyNano: A computational framework for analyzing and visualizing nanoparticle data in R. PLoS ONE 2019, 14, e0218270. [CrossRef]

92. Menon, R.; Dixon, C.L.; Sheller-Miller, S.; Fortunato, S.J.; Saade, G.R.; Palma, C.; Lai, A.; Guanzon, D.; Salomon, C. Quantitative Proteomics by SWATH-MS of Maternal Plasma Exosomes Determine Pathways Associated With Term and Preterm Birth. Endocrinology 2019, 160, 639-650. [CrossRef]

93. Sheller-Miller, S.; Trivedi, J.; Yellon, S.M.; Menon, R. Exosomes Cause Preterm Birth in Mice: Evidence for Paracrine Signaling in Pregnancy. Sci. Rep. 2019, 9, 608. [CrossRef] [PubMed]

94. Cook, J.; Bennett, P.R.; Kim, S.H.; Teoh, T.G.; Sykes, L.; Kindinger, L.M.; Garrett, A.; Binkhamis, R.; MacIntyre, D.A.; Terzidou, V. First Trimester Circulating MicroRNA Biomarkers Predictive of Subsequent Preterm Delivery and Cervical Shortening. Sci. Rep. 2019, 9, 5861. [CrossRef] [PubMed] 
95. Elovitz, M.A.; Anton, L.; Bastek, J.; Brown, A.G. Can microRNA profiling in maternal blood identify women at risk for preterm birth? Am. J. Obstet. Gynecol. 2015, 212, e1-e5. [CrossRef] [PubMed]

96. Gray, C.; McCowan, L.M.; Patel, R.; Taylor, R.S.; Vickers, M.H. Maternal plasma miRNAs as biomarkers during mid-pregnancy to predict later spontaneous preterm birth: A pilot study. Sci. Rep. 2017, 7, 815. [CrossRef] [PubMed]

97. Winger, E.E.; Reed, J.L.; Ji, X. Early first trimester peripheral blood cell microRNA predicts risk of preterm delivery in pregnant women: Proof of concept. PLoS ONE 2017, 12, e0180124. [CrossRef] [PubMed]

98. Fallen, S.; Baxter, D.; Wu, X.; Kim, T.K.; Shynlova, O.; Lee, M.Y.; Scherler, K.; Lye, S.; Hood, L.; Wang, K. Extracellular vesicle RNAs reflect placenta dysfunction and are a biomarker source for preterm labour. J. Cell. Mol. Med. 2018, 22, 2760-2773. [CrossRef]

99. Menon, R.; Debnath, C.; Lai, A.; Guanzon, D.; Bhatnagar, S.; Kshetrapal, P.; Sheller-Miller, S.; Salomon, C. Protein Profile Changes in Circulating Placental Extracellular Vesicles in Term and Preterm Births: A Longitudinal Study. Endocrinology 2020, 161, bqaa009. [CrossRef]

100. Ornoy, A.; Reece, E.A.; Pavlinkova, G.; Kappen, C.; Miller, R.K. Effect of maternal diabetes on the embryo, fetus, and children: Congenital anomalies, genetic and epigenetic changes and developmental outcomes. Birth Defects Res. C Embryo Today 2015, 105, 53-72. [CrossRef]

101. Nair, S.; Jayabalan, N.; Guanzon, D.; Palma, C.; Scholz-Romero, K.; Elfeky, O.; Zuñiga, F.; Ormazabal, V.; Diaz, E.; Rice, G.E.; et al. Human placental exosomes in gestational diabetes mellitus carry a specific set of miRNAs associated with skeletal muscle insulin sensitivity. Clin. Sci. (Lond.) 2018, 132, 2451-2467. [CrossRef]

102. Rice, G.E.; Scholz-Romero, K.; Sweeney, E.; Peiris, H.; Kobayashi, M.; Duncombe, G.; Mitchell, M.D.; Salomon, C. The Effect of Glucose on the Release and Bioactivity of Exosomes from First Trimester Trophoblast Cells. J. Clin. Endocrinol. Metab. 2015, 100, E1280-E1288. [CrossRef]

103. Jayabalan, N.; Lai, A.; Ormazabal, V.; Adam, S.; Guanzon, D.; Palma, C.; Scholz-Romero, K.; Lim, R.; Jansson, T.; McIntyre, H.D.; et al. Adipose tissue exosomal proteomic profile reveals a role on placenta glucose metabolism in gestational diabetes mellitus. J. Clin. Endocrinol. Metab. 2019, 104, 1735-1752. [CrossRef] [PubMed]

104. Jayabalan, N.; Lai, A.; Nair, S.; Guanzon, D.; Scholz-Romero, K.; Palma, C.; McIntyre, H.D.; Lappas, M.; Salomon, C. Quantitative Proteomics by SWATH-MS Suggest an Association Between Circulating Exosomes and Maternal Metabolic Changes in Gestational Diabetes Mellitus. Proteomics 2019, 19, e1800164. [CrossRef] [PubMed]

105. Ramachandrarao, S.P.; Hamlin, A.A.; Awdishu, L.; Overcash, R.; Zhou, M.; Proudfoot, J.; Ishaya, M.; Aghania, E.; Madrigal, A.; Kokoy-Mondragon, C.; et al. Proteomic analyses of Urine Exosomes reveal New Biomarkers of Diabetes in Pregnancy. Madr. J. Diabetes 2016, 1, 11-22. [CrossRef] [PubMed]

106. Almohammadi, D.; Casper, J.; Elfeky, O.; Chang, C.; Scholz-Romero, K.; Longo, S.; Duncombe, G.; Rice, G.; Salomon, C. C19MC miRNA Signatures of Placenta-Derived Exosomes in Women Diagnosed with Gestational Diabetes Mellitus. In Proceedings of the Endocrine Society's 98th Annual Meeting and Expo, Boston, MA, USA, 1-4 April 2016.

107. Gillet, V.; Ouellet, A.; Stepanov, Y.; Rodosthenous, R.S.; Croft, E.K.; Brennan, K.; Abdelouahab, N.; Baccarelli, A.; Takser, L. miRNA Profiles in Extracellular Vesicles From Serum Early in Pregnancies Complicated by Gestational Diabetes Mellitus. J. Clin. Endocrinol. Metab. 2019, 104, 5157-5169. [CrossRef] [PubMed]

108. Yoffe, L.; Polsky, A.; Gilam, A.; Raff, C.; Mecacci, F.; Ognibene, A.; Crispi, F.; Gratacós, E.; Kanety, H.; Mazaki-Tovi, S.; et al. Early diagnosis of gestational diabetes mellitus using circulating microRNAs. Eur. J. Endocrinol. 2019, 181, 565-577. [CrossRef]

109. Zhao, C.; Dong, J.; Jiang, T.; Shi, Z.; Yu, B.; Zhu, Y.; Chen, D.; Xu, J.; Huo, R.; Dai, J.; et al. Early second-trimester serum miRNA profiling predicts gestational diabetes mellitus. PLoS ONE 2011, 6, e23925. [CrossRef]

110. Zhu, Y.; Tian, F.; Li, H.; Zhou, Y.; Lu, J.; Ge, Q. Profiling maternal plasma microRNA expression in early pregnancy to predict gestational diabetes mellitus. Int. J. Gynaecol. Obstet. 2015, 130, 49-53. [CrossRef]

111. Floriano, J.F.; Willis, G.; Catapano, F.; Lima, P.R.; Reis, F.; Barbosa, A.; Rudge, M.; Emanueli, C. Exosomes Could Offer New Options to Combat the Long-Term Complications Inflicted by Gestational Diabetes Mellitus. Cells 2020, 9, 675. [CrossRef] 
112. Lai, A.; Elfeky, O.; Rice, G.E.; Salomon, C. Optimized Specific Isolation of Placenta-Derived Exosomes from Maternal Circulation. Methods Mol. Biol. 2018, 1710, 131-138.

113. Burkova, E.E.; Grigor'eva, A.E.; Bulgakov, D.V.; Dmitrenok, P.S.; Vlassov, V.V.; Ryabchikova, E.I.; Sedykh, S.E.; Nevinsky, G.A. Extra Purified Exosomes from Human Placenta Contain An Unpredictable Small Number of Different Major Proteins. Int. J. Mol. Sci. 2019, 20, 2434. [CrossRef]

114. Powe, C.E. Early Pregnancy Biochemical Predictors of Gestational Diabetes Mellitus. Curr. Diabetes Rep. 2017, 17, 12. [CrossRef] [PubMed]

115. Pillar, N.; Yoffe, L.; Hod, M.; Shomron, N. The possible involvement of microRNAs in preeclampsia and gestational diabetes mellitus. Best Pract. Res. Clin. Obstet. Gynaecol. 2015, 29, 176-182. [CrossRef]

116. Herrera-Van Oostdam, A.S.; Salgado-Bustamante, M.; López, J.A.; Herrera-Van Oostdam, D.A.; López-Hernández, Y. Placental exosomes viewed from an 'omics' perspective: Implications for gestational diabetes biomarkers identification. Biomark. Med. 2019, 13, 675-684. [CrossRef] [PubMed]

117. Mobarak, H.; Heidarpour, M.; Lolicato, F.; Nouri, M.; Rahbarghazi, R.; Mahdipour, M. Physiological impact of extracellular vesicles on female reproductive system; highlights to possible restorative effects on female age-related fertility. BioFactors 2019, 45, 293-303. [CrossRef] [PubMed]

118. Than, U.T.T.; Le, H.T.; Hoang, D.H.; Nguyen, X.-H.; Pham, C.T.; Bui, K.T.V.; Bui, H.T.H.; Nguyen, P.V.; Nguyen, T.D.; Do, T.T.H.; et al. Induction of Antitumor Immunity by Exosomes Isolated from Cryopreserved Cord Blood Monocyte-Derived Dendritic Cells. Int. J. Mol. Sci. 2020, 21, 1834. [CrossRef]

(C) 2020 by the authors. Licensee MDPI, Basel, Switzerland. This article is an open access article distributed under the terms and conditions of the Creative Commons Attribution (CC BY) license (http://creativecommons.org/licenses/by/4.0/). 